\title{
A marine sponge associated strain of Bacillus subtilis and other marine bacteria can produce anticholinesterase compounds
}

\author{
Sony Pandey ${ }^{1 *}$, Ayinampudi Sree ${ }^{1}$, Dipti Priya Sethi ${ }^{1}$, Chityal Ganesh Kumar ${ }^{2}$, Sudha Kakollu²,
} Lipsa Chowdhury ${ }^{1}$ and Soumya Suchismita Dash ${ }^{1}$

\begin{abstract}
Background: Acetylcholinesterase (AChE) inhibitors or anticholinesterases reduce the activity of enzyme acetylcholinesterase that degrades the neurotransmitter acetylcholine in the brain. The inhibitors have a significant pharmacological role in neurodegenerative diseases like Alzheimer's and Parkinson's etc. Although plants have been a significant source of these compounds, there are very few sporadic reports of microorganisms producing such inhibitors. Anticholinesterase activity in bacterial associates of marine soft corals and sponges were not previously reported.
\end{abstract}

Results: We screened 887 marine bacteria for the presence of acetylcholinesterase inhibitors, in a microplate based assay, and found that 140 (15.8\%) of them inhibit the electric eel enzyme, acetylcholinesterase. Majority of the active isolates were bacterial associates of soft corals followed by sediment isolates while most of the potent inhibitors belonged to the bacterial associates of marine sponges. Maximum inhibition (54\%) was exhibited by a bacterial strain M18SP4P (ii), isolated from the marine sponge Fasciospongia cavernosa. Based on phenotypic characterization and $16 \mathrm{~S}$ rDNA sequencing, the strain was identified as Bacillus subtilis - revealing yet another activity in a strain of the model organism that is considered to be a cell factory. TLC bioautography of the methanol extract of this culture, showed the presence of two major components having this activity, when compared to Galanthamine, the positive control.

Conclusion: From the results of our study, we conclude that acetylcholinesterase inhibitors are quite prevalent in marine bacteria, particularly the bacterial associates of marine invertebrates. Several potential AChE inhibitors in marine bacteria are waiting to be discovered to provide easily manipulable natural sources for the mass production of these therapeutic compounds.

Keywords: Acetylcholinesterase inhibitors, Galanthamine, Alzheimer's disease, Fasciospongia cavernosa, Marine bacteria, Screening, Soft coral, marine sediment

\section{Introduction}

Acetylcholinesterase inhibitors (AChEIs) work by increasing the concentration of acetylcholine (ACh) in the brain, due to reduction in the rate of its breakdown by acetylcholinesterase (AChE). These inhibitors, naturally found in venoms, have a range of applications from pharmaceuticals to insecticides and weapons like nerve gas [1]. An

\footnotetext{
* Correspondence: sony@immt.res.in

${ }^{1}$ Environment and Sustainability Department, CSIR - Institute of Minerals and Materials Technology, Bhubaneswar 751 013, India

Full list of author information is available at the end of the article
}

important therapeutic use of $\mathrm{AChE}$ inhibitors is in the treatment of dementia associated with Alzheimer's disease. There is no cure yet for this disease; four out of five FDA approved drugs are AChE inhibitors, which provide symptomatic relief, by improving signal transfer in the brain and slowing down the neurofibrillary degeneration [2]. However, the importance of acetylcholinesterase inhibitors cannot be underestimated because recent research shows that these inhibitors protect brain cells against free radical injury and $\beta$-amyloid toxicity in Alzheimer's disease (AD) [3]. Despite the quest for new treatments to stop, slow or 
prevent $\mathrm{AD}$, researchers around the world are looking for new sources of AChE inhibitors also, because of the concerns around the bioavailability and side-effects issues, associated with the existing, mostly synthetic, drugs for AD.

The natural sources are favoured for screening AChE inhibitors since they present enormous possibilities of discovering novel chemical structures with better properties. Majority of $\mathrm{AChE}$ inhibitors are derived from plants $[1,4]$, but they were also isolated from extracts of some algae, fungi, cyanobacteria, marine phytoplankton and marine sessile organisms like sponges and soft corals. For example, anticholinesterase compounds like the arisugacin, sporothrin and curvularin have been isolated from fungi [5-7]; sargaquinoic acid was found in marine alga Sargassum sagamianum [8] and recently, biruloquinone isolated from a lichen forming fungi Cladonia macilenta, was identified as an inhibitor of acetylcholinesterase [9].

Very few AChE inhibitor compounds have been isolated from the bacterial sources. AChEI activity in bacteria was first reported in Streptomyces antibioticus, when two related furo-dioxa-phosphepin organophosphorus compounds, used in pesticides, were isolated from its cultures [10]. Subsequently, another AChE inhibitor, cyclophostin was found in Strepomyces lavendulae [11]. In the recent past, marinoquinoline A (a new alkaloid possessing pyrroloquinoline skeleton) was isolated from a marine gliding bacterium Rapidithrix thailandica (phylum Bacteroidetes). The AChE inhibitory activity of marinoquinoline A was discovered, after the compound was found to be structurally related to tacrine, which is an AChE inhibitor [12]. Marinoquinoline A was again isolated from another novel marine Bacteroidetes member Ohtaekwangia kribbensis [13]; hence this organism may, as well, inhibit AChE.

The latest discoveries about marinoquinoline A, coupled with, the reports claiming novel inhibitors from chemical investigations of marine sessile organisms [14-16], strongly indicate the potential of bacteria as a source of these important compounds from marine samples. Considering the enormous diversity of marine microorganisms, we set out to find the prevalence of acetylcholinesterase inhibitors in marine bacteria isolated from different samples of marine sponges, soft corals and sediments, using a high throughput microplate based assay. In this research report, we present an interesting finding that uncovers another activity - AChE inhibition - of a robust microorganism, amenable to manipulation and biotechnological scale-up for the production process.

\section{Results}

\section{Screening assay}

Out of the 887 isolates tested for AChE inhibition activity, 140 isolates were found to be positive (Table 1; details in Additional file 1: Table S1). The proportion of positives hits was more in soft corals $(n=16$ out of 66 ) followed by sediment ( $n=53$ out of 321$)$ and sponges ( $\mathrm{n}=71$ out of 500 ) as shown in Figure 1. The positive control, $0.1 \mu \mathrm{M}$ galanthamine, inhibited $74 \% \mathrm{AChE}$ while at higher concentrations, it showed 100\% inhibition. Figure 2 shows a comparison of AChE inhibition activity of the eight sponge isolates taken in this study. Among the sponge samples Siphonodictyon coralliphagum isolates were the most active and potent inhibitors, followed by Fasciospongia cavernosa, Acanthella cavernosa, Dragmacidon agariciforme, Rhabdastrella globostellata, Xestospongia testudinaria and Leiodermatium pfeifferae; however, none of the 77 isolates of Sarcotragus fasciculatus were active. The sponge isolates have a comparatively large number of potent inhibitors, i.e, they showed higher percentages of inhibition (Additional file 1: Table S1). An isolate of the sponge Fasciospongia cavernosa, strain M18SP4Q (ii),

Table 1 AChE inhibition activity in marine isolates

\begin{tabular}{|c|c|c|c|c|c|}
\hline SI. no. & Isolation source & $\begin{array}{l}\text { No. of isolates } \\
\text { screened }\end{array}$ & No. of active isolates & $\begin{array}{l}\text { Percentage of active } \\
\text { isolates }(\%)\end{array}$ & $\begin{array}{l}\text { No. of isolates } \\
\text { showing }>10 \% \text { AChE } \\
\text { inhibition activity }\end{array}$ \\
\hline 1. & Acanthella cavernosa & 39 & 9 & 23 & 0 \\
\hline 2. & Dragmacidon agariciforme & 110 & 17 & 15 & 4 \\
\hline 3. & Fasciospongia cavernosa & 8 & 2 & 25 & 1 \\
\hline 4. & Leiodermatium pfeifferae & 72 & 7 & 10 & 0 \\
\hline 5. & Rhabdastrella globostellata & 127 & 18 & 14 & 2 \\
\hline 6. & Siphonodictyon coralliphagum & 31 & 13 & 42 & 12 \\
\hline 7. & Xestospongia testudinaria & 36 & 5 & 14 & 4 \\
\hline 8. & Sarcotragus fasciculatus & 77 & 0 & 0 & 0 \\
\hline 9. & Soft coral & 66 & 16 & 24 & 2 \\
\hline \multirow[t]{2}{*}{10.} & Sediment & 321 & 53 & 17 & 26 \\
\hline & Total & 887 & 140 & & 51 \\
\hline
\end{tabular}




\section{Source of AChEI positive is olates}

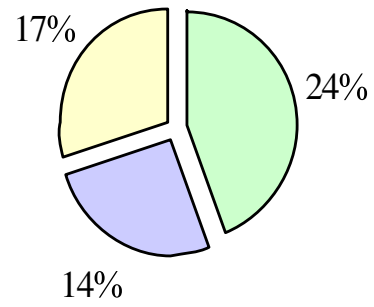

\section{$\square$ Soft corals $\square$ Sponges $\square$ Sediment}

Figure 1 The distribution of AChEl positive isolates among soft corals, sponges and sediment.

showed the maximum percentage (54\%) of AChE inhibition.

\section{Identification of M18SP4Q (ii)}

The bacterial strain M18SP4Q (ii) was Gram positive slender rod with the spore in non-bulging sporangia. The strain was aerobic, grew in the presence of $6.5 \%$ $\mathrm{NaCl}$ and tested positive for starch, VP and Citrate; details are available in Table 2. The 16S rDNA sequence (GenBank accession number KC886741) of this strain showed 99.86\% similarity with the type strain of Bacillus subtilis subsp. subtilis. The phenotypic characters combined with 16S rRNA gene sequence confirmed the identity of the strain as Bacillus subtilis. The evolutionary relationship of this strain M18SP4Q (ii), with the 16S rRNA gene sequences of its closely related strains is shown in the Neighbor-Joining phylogenetic tree (Figure 3).

\section{TLC bioautography of M18SP4Q (ii)}

TLC bioautography, performed to analyze the inhibitor compound in the crude extract of M18SP4Q (ii) (extract code IMM 46), showed the presence of two major compounds at $R f-0.45$ and 0.85 in IMM46, while the galanthamine spot was observed at $R f-0.58$; indicating that the compounds are chemically different from galanthamine (Figure 4).

\section{Discussion}

Many prominent researchers have reviewed the literature on marine natural products and unequivocally hailed the bioactive potential of marine microbes. Some of them proposed and demonstrated that marine invertebrate associated microbes are the primary producers of biologically active metabolites and play an important role in the host defense $[20,21]$. Nonetheless, very few studies have identified the microbial producers of spongeassociated compounds; on the other hand, few microorganisms of the diverse microbial community associated with the sponges have a known function. Although bridging this gap is not so easy for a single research group, we initiated a basic search for a function, i.e., acetylcholinesterase inhibition, in the diverse microbial associates of sponges, sediment and soft corals. This research report is the first account of AChE inhibition activity in the microbial associates of the marine invertebrates and sediment.

\section{Screening results analysis}

Our findings showed a significant number, constituting $16 \%$, of the isolates screened in this study with AChE inhibition activity. The major share of the positive cultures comes from soft corals followed by the sediment and sponge samples (Figure 1). Literature reviews of natural product $\mathrm{AChE}$ inhibitors shows that the majority of AChEIs are alkaloids followed by mono-, di-, tri- and sesqui-terpenes; while a few flavonoids, coumarins and other compounds are also on the list [22]. Soft corals are known to produce different types of terpenes; as a recent example, Bonnard et al. [14] discovered novel bioactive natural terpenes upon chemical investigations of comorian soft corals. There are some studies showing

\section{AChE inhibition activity among sponge isolates}

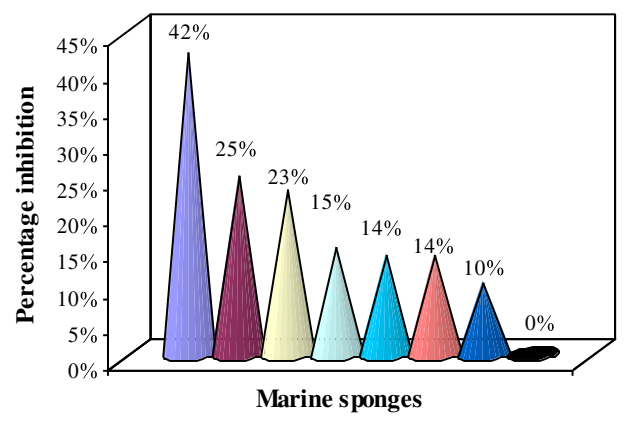

$\square$ Siphonodictyon coralliphagum

$\square$ Fasciospongia cavernosa

$\square$ Acanthella cavernosa

$\square$ Dragmacidon agariciforme

$\square$ Rhabdastrella globostella

$\square$ Xestospongia testudinaria

$\square$ Leiodermatium pfeifferae

- Sarcotragus fasciculatus

Figure 2 Comparison of AChE inhibition activity among sponge isolates. 
Table 2 Biochemical characterization data of M18SP4Q (ii)

\begin{tabular}{|c|c|}
\hline Tests & M18SP4Q (ii) \\
\hline \multicolumn{2}{|l|}{ Colony morphology } \\
\hline Configuration & Circular \\
\hline Margin & Rhizoid \\
\hline Elevation & Flat \\
\hline Surface & Pale \\
\hline Pigment & - \\
\hline Opacity & Opaque \\
\hline Gram's reaction & Positive \\
\hline Cell shape & Rods \\
\hline Arrangement & Singles \& pairs \\
\hline Spore (s) & Present \\
\hline Endospore & + \\
\hline Position & Subterminal \\
\hline Shape & Oval \\
\hline Sporangia bulging & No \\
\hline Motility & + \\
\hline Temperature requirement & 15 to $40^{\circ} \mathrm{C}$ \\
\hline pH requirement & $6-8$ \\
\hline Growth at $6.5 \% \mathrm{NaCl}$ & + \\
\hline Growth under anaerobic condition & - \\
\hline Voges Proskauer test & + \\
\hline Citrate utilization & + \\
\hline Starch hydrolysis & + \\
\hline Nitrate reduction & + \\
\hline Catalase test & + \\
\hline Oxidase test & - \\
\hline
\end{tabular}

coral-associated microorganisms as the biosynthetic source of terpene derivatives; like, the dinoflagellate Symbiodinium sp. was identified as a producer of pseudopterosins, the pharmacologically important diterpene glycosides, in a gorgonian soft coral [23]. Although these findings are not connected, it is apparent that the AChE inhibiting terpenes have been found in different soft coral extracts, and coral microbial symbionts too have been shown to produce a class of terpenes. A very recent study, using the new technique of "genome mining" [24], also reveals tremendous biosynthetic potential of several bacterial species for terpene synthesis. Hence, it may be assumed that the terpenes isolated from different soft coral may have originated in the associated microbes.

Other chemical compounds from invertebrate extracts may show similar links if studied in depth because literature is replete with reports which show the involvement of different chemical classes of compounds in many of the biological activities. If such different classes of compounds can show the same activity, the chances of these compounds being found in the microbial world are not surprising. It has been observed in chemical investigations of natural extracts that the novel compounds are mostly variants or derivatives of existing major chemical classes of compounds. So, the general opinion of microbes being the primary producers of sponge or coral metabolites may gather more proofs with the concerted efforts of marine microbiologists and natural product chemists. This also explains why such large numbers of marine isolates exhibited AChEI activity.

\section{AChEls in sponge microbes}

An examination of Table 1 shows that the maximum number of active isolates belong to the sponge Siphonodictyon coralliphagum, exhibiting consistently higher percentages of inhibition as compared to all other isolates. Earlier, a number of new meroterpenoid and spirosesquiterpene aldehyde compounds, like corallidictyals and liphagal; siphonodictyal sulfate and akadisulfates, have been isolated from the extracts of the sponge Siphonodictyon coralliphagum (= Aka coralliphaga); which showed protein kinase C inhibition, PI3K inhibitory activity and radical-scavenging activity respectively [25-27]. Some siphonodictyals and corallidictyals have also been reported to have antimicrobial activity $[28,29]$. The other sponges from which compounds with antimicrobial activity have been isolated are Fasciospongia cavernosa [30] and Acanthella cavernosa [31-33]. A careful study of the previous literature showed that several compounds with AChEI activity, isolated from the sponges, mostly derivatives of alkaloids and terpenes [22]. However, anticholinesterase activity of the compounds of the above mentioned sponges or their microbial associates was not known so far, which may be due to limited research in this area. Recently, a web resource DESMSCI - was developed for knowledge generation on marine sponge compounds interactions including a useful "hypothesis generation" feature [34]. Using this web resource, the authors could generate and theoretically validate a hypothesis, by linking terms from different dictionaries. According to this hypothesis there is a possibility of finding a novel mode of action for a sponge compound variolin (an alkaloid) in $\mathrm{AD}$. Thus, it is apparent that sponge compounds, like alkaloids, may not just inhibit $\mathrm{AChE}$ to provide symptomatic relief in $\mathrm{AD}$, but may even have a disease modifying effect which needs to be studied in depth.

\section{AChEl in Bacillus subtilis}

The isolate M18SP4Q (ii), which showed the maximum percentage of AChE inhibition in the present screening, was taxonomically identified as Bacillus subtilis. This omnipresent saprophytic bacterium can survive in extreme conditions and is ecologically important due to its 


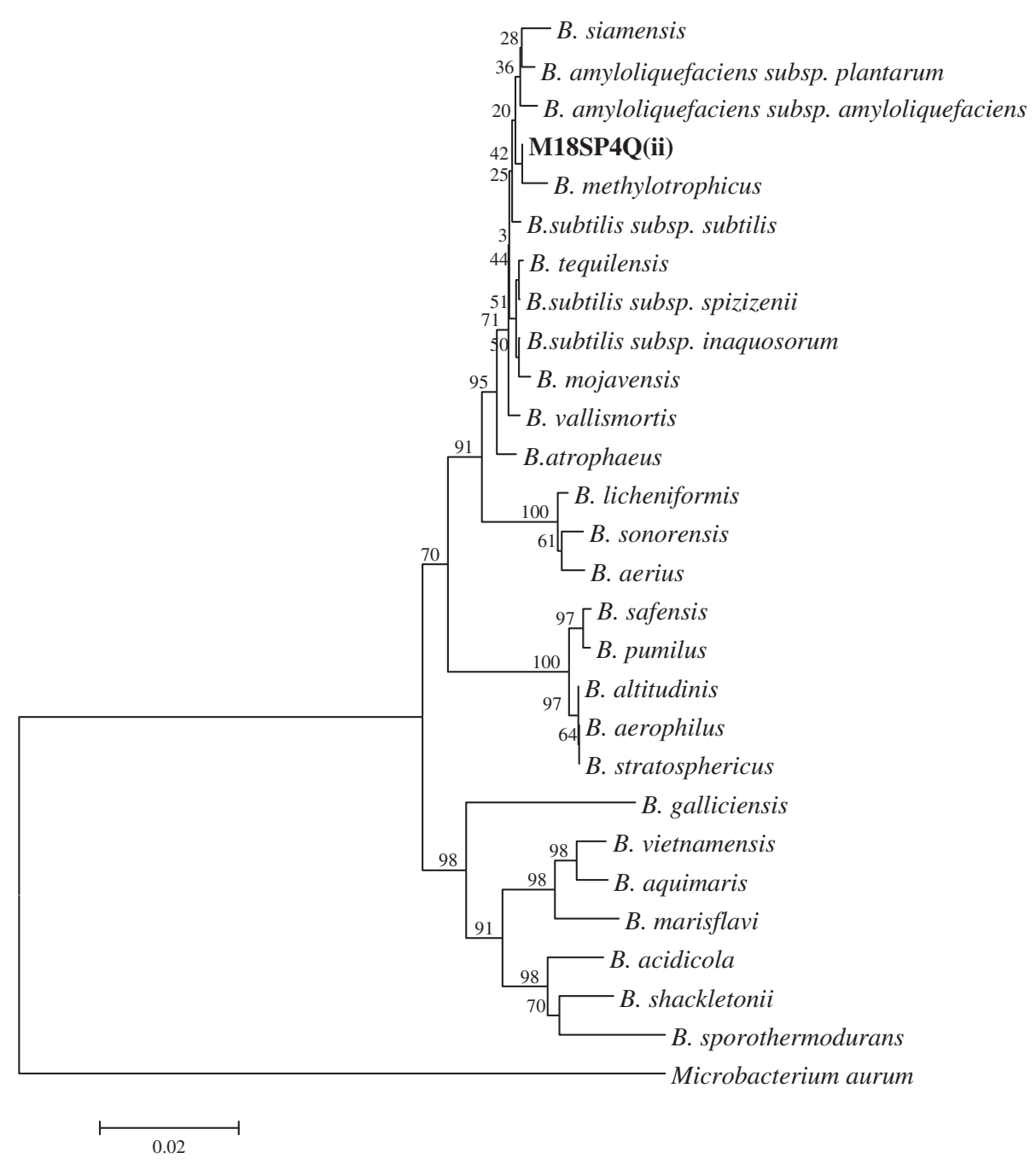

Figure 3 The evolutionary relationship of the strain M18SP4Q (ii) with the 16S rRNA gene sequences of its closely related strains is shown in the neighbour joining phylogenetic tree. The evolutionary history was inferred using the Neighbor-Joining method [17]. The optimal tree with the sum of branch length $=0.33445952$ is shown. The percentage of replicate trees in which the associated taxa clustered together in the bootstrap test (1000 replicates) is shown above the branches [18]. The tree is drawn to scale, with branch lengths in the same units as those of the evolutionary distances used to infer the phylogenetic tree. The evolutionary distances were computed using the p-distance method [19] and are in the units of the number of base differences per site. The analysis involved 28 nucleotide sequences. All ambiguous positions were removed for each sequence pair. There were a total of 1539 positions in the final dataset.

ability to produce a wide variety of enzymes; as a result, they play varied role from nutrient recycling to heavy metal accumulation or detoxification. Besides enzymes, they also produce antibiotics and their biosurfactant lipopeptides, called surfactins, have been reported to have mosquito larvicidal and pupicidal activity [35-37]. It is also commercially used in the production of amylase, protease, lipase, amino acids, inosine, ribosides, hyaluronic acid and polyhydroxybutarate. Bacillus subtilis is a favorable workhorse for the biotechnology industry because it is highly responsive to genetic manipulation. Recently, van Dijl and Hecker [38] suggested that Bacillus subtilis can be engineered into next-generation super- secreting cell factory using combined systems and synthetic biology approach. Thus, the detection of acetylcholinesterase inhibition in a Bacillus subtilis strain is certainly a significant finding.

\section{Diversity of bacteria with AChEl activity}

Microbes producing AChE inhibitors are few and far between in the past literature. In our taxonomic investigation of some marine bacteria, we found several different genera of bacteria produce AChE inhibitors, like, Psychrobacter, Microbacterium, Stenotrophomonas, Planococcus, Nocardia, Streptomyces sp., Leucobacter, Bacillus sp., Virgibacillus and Brevibacterium sp. (Additional file 2: 


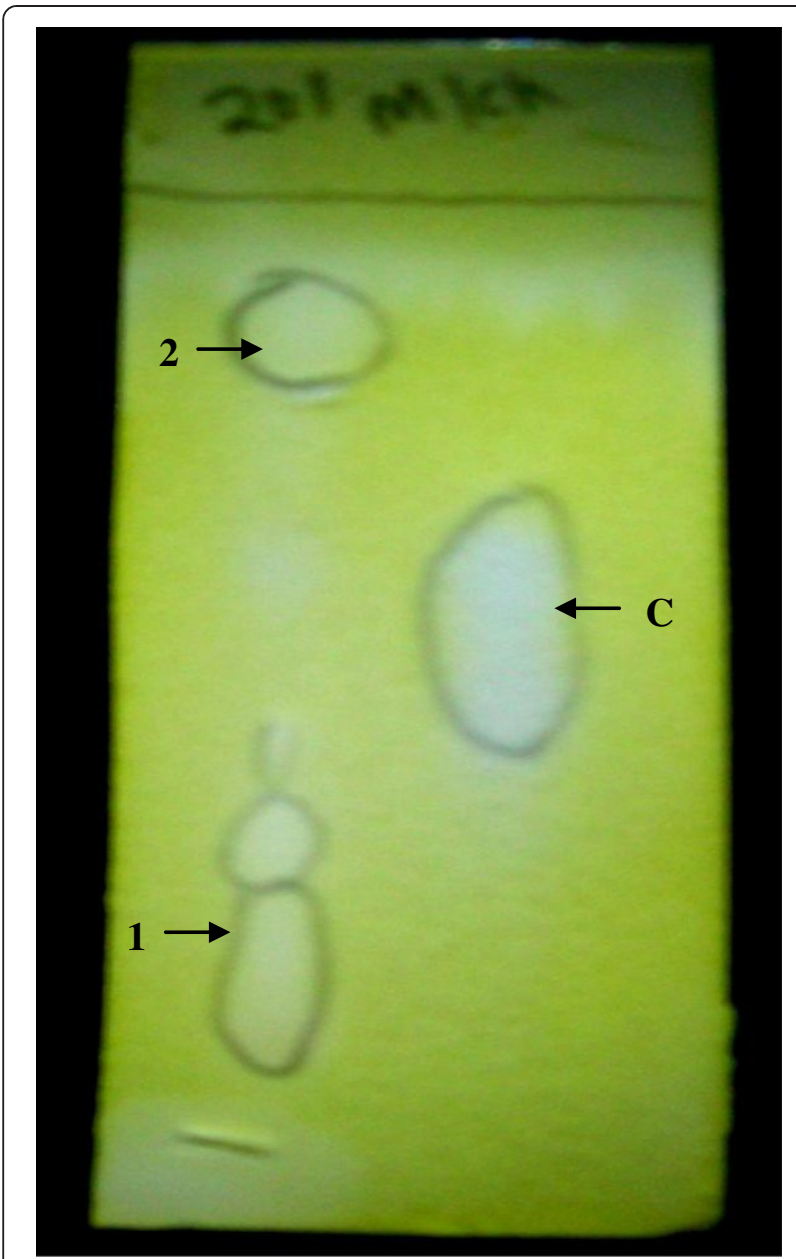

Figure 4 TLC bioautography of IMM46 extract showing two compounds $1 \& 2$ containing the inhibitor of acetylcholinesterase, and C - control ( $0.1 \mu \mathrm{M}$ Galanthamine).

Table S2), apart from the Bacillus subtilis strain. Involvement of diverse groups of microorganisms in AChE inhibitor production increases the chances of finding structurally unique metabolites. Recently, phylogenetically diverse urea utilizing microbes associated with the sponge Xestospongia testudinaria was reported, and our group has also reported a diverse marine microbial community producing betaglucosidase inhibitors $[39,40]$. The research on marine bacteria has not been extensive; therefore, the bioactive strains isolated from marine samples may present themselves as new to natural products research. Thus, the efforts to screen natural products from marine bacteria for industrially important activities are desirable conjointly with the molecular techniques in the metagenomic era.

\section{Conclusion}

Acetylcholinesterase inhibitors in bacteria have not received adequate attention of the researchers. Our assumption on the preponderance of AChEIs in marine bacteria proved to be correct. The AChEI activity has been detected in good numbers, in the microbial associates of soft corals, sponges and sediments. Bacillus subtilis - a well studied and exploited species - presented yet another activity, though it remains to be seen whether the compound responsible for this activity is new or known. These results imply that many anticholinesterase compounds are waiting to be discovered in marine bacteria of different lineages. Chemical investigation of hits from this study may be pursued in order to use these compounds. In future, the marine microbial secondary metabolites may be considered for further studies in the development of drugs for the treatment of AD because the present work shows a significant number of marine bacteria possess anticholinesterase activity.

\section{Materials and methods}

\section{Chemicals used}

AChE Type VI-S, EC 3.1.1.7, from electric eel (Electrophorus electricus) and galanthamine hydrobromide from Lycoris sp. were purchased from Sigma (St. Louis, MO, USA). Acetylthiocholine iodide (ATCI), 5,5'-dithiobis-(2nitrobenzoic acid) (DTNB), bovine serum albumin (BSA), dimethylsulfoxide (DMSO), Tris- $\mathrm{HCl}$ and microbiological media were procured from HiMedia Laboratories Pvt. Ltd., Mumbai, India. The chemicals used in the study were of the highest purity and used without further purification.

\section{Buffers and reagents}

A stock solution of $1.17 \mathrm{mg} / \mathrm{ml}$ acetylcholinesterase (425.94 U/mg) was prepared with $0.1 \%$ BSA in buffer A (50 mM Tris- $\mathrm{HCl}, \mathrm{pH}-8$ ) and stored in $-20^{\circ} \mathrm{C}$, and working solutions of $0.01 \mathrm{U} / \mathrm{ml}$ and $3 \mathrm{U} / \mathrm{ml}$ were prepared by dilution. Phosphate buffer ( $\mathrm{pH}$ 7.5), 1.5 mM ATCI reconstituted in phosphate buffer and $3 \mathrm{mM}$ DTNB in phosphate buffer. Galanthamine $5 \mathrm{mg} / \mathrm{ml}$ was dissolved in methanol and further diluted in phosphate buffer to make a working stock of $0.1 \mu \mathrm{M} \mathrm{ml}^{-1}$.

\section{Bacterial strains and culture conditions}

A large number of marine microorganisms were isolated from the samples of marine sponges, soft corals and sediment, collected from the Bay of Bengal on the east coast of India. The initial isolations were carried out on a variety of media prepared in seawater at temperatures ranging from $20-30^{\circ} \mathrm{C}$. Many of these isolates were screened for the investigation of the presence of acetylcholinesterase inhibitors in the associates of marine sponges, soft corals and sediment samples. In this study, a total of 887 marine microorganisms isolated from samples of 8 sponges [total $\mathrm{n}=500 ;$ Rhabdastrella globostella $(\mathrm{n}=127)$, Acanthella cavernosa $(\mathrm{n}=39)$, Dragmacidon agariciforme $(\mathrm{n}=110)$, Leiodermatium pfeifferae $(\mathrm{n}=72)$, Fasciospongia cavernosa $(\mathrm{n}=08)$, Xestospongia testudinaria $(\mathrm{n}=36)$, Siphonodictyon 
coralliphagum $(\mathrm{n}=31)$ and Sarcotragus fasciculatus $(\mathrm{n}=77)$ ], 2 unidentified soft corals $(\mathrm{n}=66)$ and 5 sediments $(n=321)$ were investigated. All these organisms grew on Nutrient Agar media (HiMedia, Mumbai) prepared in $50 \%$ aged natural seawater at $30^{\circ} \mathrm{C}$ within 48 72 hrs.

\section{Extraction of metabolites}

The microbial metabolites were extracted as described in Pandey et al. [40]. Briefly, the cultures were grown in $50 \mathrm{ml}$ of Nutrient Broth with $50 \%$ seawater, at $30^{\circ} \mathrm{C} / 48 \mathrm{hrs}$ and $200 \mathrm{rpm}$ in a rotary shaker, followed by centrifugation at $9000 \mathrm{rpm} / 20 \mathrm{~min}$ to remove the cell mass. The supernatant was mixed with 10\% Diaion HP-20 (Sigma) resin for $30 \mathrm{~min}$ on a magnetic stirrer. Then the Diaion resin along with supernatant was packed in a glass column, washed with $15 \mathrm{ml}$ distilled water, and eluted with $20 \mathrm{ml}$ methanol. The collected methanol was evaporated, and the extract was dissolved in DMSO.

\section{AChE inhibition assay}

AChE inhibitory activity was tested using a microplate assay based on the modified method of Ellman et al. [41]. The enzyme hydrolyzed the substrate acetylthiocholine resulting in the product thiocholine which reacts with Ellman's reagent (DTNB) in situ and gives the yellow coloured chromophore of 5-thio-2-nitrobenzoic acid (TNB), which can be detected at $405 \mathrm{~nm}$. The absorption intensity of TNB adduct $(405 \mathrm{~nm})$ is proportional to the formation of thiocholine, therefore, the AChE activity. In each well of the 96-well microtiter plate, $5 \mu \mathrm{l}$ of microbial extract and $10 \mu \mathrm{l}$ of $0.01 \mathrm{U} \mathrm{ml}^{-1}$ of acetylcholine esterase were incubated at $4^{\circ} \mathrm{C}$ for $20 \mathrm{~min}$ before the addition of $10 \mu \mathrm{l}$ of $1.5 \mathrm{mM}$ ATCI in phosphate buffer $(\mathrm{pH} 7.5), 60 \mu \mathrm{l}$ of $3 \mathrm{mM}$ DTNB in phosphate buffer ( $\mathrm{pH} 7.5), 60 \mu \mathrm{l}$ of $0.1 \mathrm{M}$ phosphate buffer ( $\mathrm{pH} 7.5$ ) and absorbance was measured at $405 \mathrm{~nm}$ every $30 \mathrm{~s}$ for 4 min $\times 8$ times on a TRIAD multimode reader (Dynex Technologies, Inc., Chantilly, VA). The rate of reactions was calculated using the Manager software of the multimode reader. Percentage of inhibition was calculated by comparing the rates for each sample with respect to the blank (10\% DMSO in buffer). Galanthamine hydrobromide $\left(0.1 \mu \mathrm{M} \mathrm{ml}^{-1}\right)$ in DMSO solvent was used as a positive control. Each assay was performed in triplicate, and the AChE inhibitory values are the average of three independent experiments. The percent inhibition was calculated using the following equation:

$$
\% \text { Inhibition }=\frac{\mathrm{A}_{\text {control }}-\mathrm{A}_{\text {sample }}}{\mathrm{A}_{\text {control }}} \times 100
$$

where $A_{\text {sample }}$ was the absorbance of the sample microbial extract, and $A_{\text {control }}$ was the absorbance of the blank reaction mixture without the inhibitor - negative control.

\section{TLC bioautography}

TLC bioautographic assay was carried out for the crude extract (IMM46), from the isolate M18SP4Q (ii) that showed the highest inhibition of AChE, as described by Rhee et al. [42], but with some modifications in the reagent concentrations. The substrate ATCI and chromogen DTNB was prepared as $2 \mathrm{mM}$ solutions in $10 \mathrm{ml}$ of buffer A. TLC assay was done on Silicagel 60 F $254 \mathrm{~nm}$ plates of $0.2 \mathrm{~mm}$ thickness with $1 \mu \mathrm{L}$ each of M18SP4Q (ii) extract $(100 \mathrm{mg} / \mathrm{ml})$ and $1 \mu \mathrm{L}$ of $0.1 \mu \mathrm{M} \mathrm{ml}^{-1}$ galanthamine spotted on the plate, developed in chloroform:methanol (8:2) in the mobile phase. After the TLC plate was developed, equal volume of $2 \mathrm{mM}$ solutions of ATCI and DTNB was sprayed on the TLC plate until the plate was saturated. The plate was air dried for $5 \mathrm{~min}$ and then the enzyme $10 \mathrm{ml}$ of $3 \mathrm{U} / \mathrm{ml} \mathrm{AChE} \mathrm{enzyme} \mathrm{solution} \mathrm{-} \mathrm{was} \mathrm{sprayed} \mathrm{on}$ the TLC plate. Yellow colour appeared within 5-10 min on the TLC plate except in places where the inhibitor was present.

\section{Microbial identification}

The isolate, M18SP4Q (ii), was identified by partial $16 \mathrm{~S}$ rRNA gene sequencing and phenotypic characterization [43]. The colony and cell morphology, including spores, were characterized, and starch, nitrate, $\mathrm{VP}$ and $\mathrm{NaCl}$ tolerance tests were performed as described by Claus and Berkeley [44]. The 16S rRNA gene based identification was done as described in Pandey et al. (36). Briefly, a $25 \mu \mathrm{l}$ PCR reaction was set up with $10 \mathrm{pmol}$ primers $27 \mathrm{~F}$ and 1492R, $150 \mathrm{ng}$ DNA, $5 \mathrm{mM}$ dNTPs, $1 \times$ Taq polymerase buffer containing $15 \mathrm{mM} \mathrm{MgCl}_{2}$ and $0.5 \mu \mathrm{l}$ of Taq DNA polymerase ( $5 \mathrm{U} / \mu \mathrm{l}$, Fermentas) as per the programme: $94^{\circ} \mathrm{C}$ for $5 \mathrm{~min}, 30$ cycles of $94^{\circ} \mathrm{C}$ for $1 \mathrm{~min}$, $50^{\circ} \mathrm{C}$ for $1 \mathrm{~min}, 72^{\circ} \mathrm{C}$ for $2 \mathrm{~min}$ and $72^{\circ} \mathrm{C}$ for $10 \mathrm{~min}$. The PCR product was separated on $1 \%$ agarose gel, and the DNA fragments were extracted. The purified $16 \mathrm{~S}$ rDNA was sequenced in Beckman Coulter Ceq 8000 genetic analysis system. The sequence thus obtained was deposited in GenBank and aligned with the other sequences using BLAST program in NCBI (http://blast.ncbi.nlm.nih. gov). The EzTaxon server 2.1 (http://eztaxon-e.ezbiocloud. net/) was also used to obtain the closest matching type strain sequences from the database. The identity of the strain was established based on the phenotypic characters and sequence identity.

\section{Phylogenetic analysis}

The 16S rDNA sequences of the closest relatives (type strains) of the strain M18SP4Q (ii) were retrieved from EzTaxon, and multiple sequence alignment was performed using Clustal_X program [45]. The evolutionary relatedness 
of the strain was inferred using the Neighbor-Joining method, distance calculated using the p-distance method, followed by bootstrap test in 1000 replicates for each cluster and the phylogenetic tree was drawn in MEGA5.0 program available at http://www.megasoftware.net/ [46].

\section{Additional files}

Additional file 1: Table S1. Percentage of AChE inhibition in extracts of marine isolates.

Additional file 2: Table S2. Identity of some AChEl positive strains based on morphological characters and 16S rRNA gene sequence match.

\section{Competing interests}

The authors declare no competing interests.

\section{Authors' contributions}

SP contributed to the design of experiments, acquisition, analysis and interpretation of data, and drafted the manuscript. AS conceived and designed the work on marine microbes and anticholinesterase inhibitors, collected marine sponge, soft coral and sediment samples and helped in editing of the manuscript. CGK contributed to the editing of the manuscript, design of experiments related to anticholinesterase screening assays, acquisition and interpretation of data. DPS, SK, LC and SSD helped in execution of experimental work and acquisition of data. All authors have read and approved the final manuscript.

\section{Acknowledgements}

The authors are thankful to Council of Scientific and Industrial Research for funding the work and Director CSIR-IMMT for the infrastructure support. We gratefully acknowledge Dr. Tapan Chakrabarti, former Head and founder of Microbial Type Culture Collection - an International Depository Authority, Chandigarh, India, for critically examining the manuscript.

\section{Author details}

${ }^{1}$ Environment and Sustainability Department, CSIR - Institute of Minerals and Materials Technology, Bhubaneswar 751 013, India. ${ }^{2}$ Medicinal Chemistry and Pharmacology Division, CSIR- Indian Institute of Chemical Technology, Uppal Road, Hyderabad 500 007, India.

Received: 10 January 2014 Accepted: 12 February 2014 Published: 15 February 2014

\section{References}

1. Houghton PJ, Rena Y, Howesb MJ: Acetylcholinesterase inhibitors from plants and fungi. Nat Prod Rep 2006, 23:181-199.

2. Alzheimer's Association at http://www.alz.org/research/science/ alzheimers disease treatments.asp.

3. Tabet N: Acetylcholinesterase inhibitors for Alzheimer's disease: antiinflammatories in acetylcholine clothing! Age Ageing 2006, 35:336-338.

4. Williams P, Sorribasab A, Howesc MJR: Natural products as a source of Alzheimer's drug leads. Nat Prod Rep 2011, 28:48-77.

5. Otoguro K, Kuno F, Ōmura S: Arisugacins, selective acetylcholinesterase inhibitors of microbial origin. Pharmacol \& Ther 1997, 76(1-3):45-54.

6. Wen L, Cai X, Xu F, She Z, Chan WL, Vrijmoed LL, Jones EB, Lin Y: Three metabolites from the mangrove endophytic fungus Sporothrix $s p$. (\#4335) from the South China Sea. J Org Chem 2009, 74(3):1093-1098.

7. Kumar CG, Mongolla P, Sujitha P, Joseph J, Babu KS, Suresh G, Ramakrishna KV, Purushotham U, Sastry GN, Kamal A: Metabolite profiling and biological activities of bioactive compounds produced by Chrysosporium lobatum strain BK-3 isolated from Kaziranga National Park, Assam India. Springerplus 2013, 2(1):122. doi:10.1186/2193-1801-2-122.

8. Choi BW, Ryu G, Park SH, Kim ES, Shin J, Roh SS, Shin HC, Lee BH: Anticholinesterase activity of plastoquinones from Sargassum sagamianum: lead compounds for Alzheimer's disease therapy. Phytother Res 2007, 21:423-426.
9. Luo H, Li C, Kim JC, Liu Y, Jung JS, Koh YJ, Hur JS: Biruloquinone, an acetylcholinesterase inhibitor produced by lichen-forming fungus Cladonia macilenta. J Microbiol Biotechnol 2013, 23(2):161-166.

10. Neumann R, Peter HH: Insecticidal organophosphates: nature made them first. Experientia 1987, 43:1235-1237

11. Kurokawa T, Suzuki K, Hayaoka T, Nakagawa T, Izawa T, Kobayashi M, Harada N: Cyclophostin, acetylcholinesterase inhibitor from Streptomyces lavendulae. J Antibiot 1993, 46:1315-1318.

12. Sangnoi Y, Sakulkeo O, Yuenyongsawad S, Kanjana-opas A, Ingkaninan K, Plubrukarn A, Suwanborirux K: Acetylcholinesterase-inhibiting activity of pyrrole derivatives from a novel marine gliding bacterium, Rapidithrix thailandica. Mar Drugs 2008, 6(4):578-586.

13. Okanya PW, Mohr Kl, Gerth K, Jansen R, Müller R: Marinoquinolines A-F, pyrroloquinolines from Ohtaekwangia kribbensis (Bacteroidetes). J Nat Prod 2011, 74(4):603-608.

14. Bonnard I, Jhaumeer-Laulloo SB, Bontemps N, Banaigs B, Aknin M: New lobane and cembrane diterpenes from two Comorian soft corals. Mar Drugs 2010, 8:359-372

15. Sepcić K, Guella G, Mancini I, Pietra F, Serra MD, Menestrina G, Tubbs K, Macek P, Turk T: Characterization of anticholinesterase-active 3alkylpyridinium polymers from the marine sponge Reniera sarai in aqueous solutions. J Nat Prod 1997, 60(10):991-996.

16. Langjae R, Bussarawit S, Yuenyongsawad S, Ingkaninan K, Plubrukarn A: Acetylcholinesterase-inhibiting steroidal alkaloid from the sponge Corticium sp. Steroids 2007, 72:682-685.

17. Saitou N, Nei M: The neighbor-joining method: a new method for reconstructing phylogenetic trees. Mol Biol Evol 1987, 4:406-425.

18. Felsenstein J: Confidence limits on phylogenies: an approach using the bootstrap. Evolution 1985, 39:783-791.

19. Nei M, Kumar S: Molecular evolution and phylogenetics. Oxford University Press: New York; 2000.

20. Newmann DJ, Hill RT: New drugs from marine microbes: the tide is turning. J Ind Microbiol Biotechnol 2006, 33:539-544.

21. Webster NS, Taylor MW: Marine sponges and their microbial symbionts: love and other relationships. Environ Microbiol 2012, 14(2):335-346.

22. Filho JMB, Medeiros KCP, Diniz MF, Batista LM, Filho PFA, Silva S, Cunha EVL, Almeida JRGS, Quintans $L$ : Natural products inhibitors of the enzyme acetylcholinesterase. Braz J Pharmacog 2006, 16(2):258-285.

23. Mydlarz LD, Jacobs R, Boehnlein J, Kerr RG: Pseudopterosin biosynthesis in Symbiodinium sp., the dinoflagellate symbiont of Pseudopterogorgia elisabethae. Chem Biol 2003, 10(11):1051-1056

24. Cane DE, Ikeda $\mathrm{H}$ : Exploration and mining of the bacterial terpenome. Acc Chem Res 2012, 45(3):463-472.

25. Chan JA, Freyer AJ, Carté BK, Hemling ME, Hofmann GA, Mattern MR, Mentzer MA, Westley JW: Protein kinase C inhibitors: novel spirosesquiterpene aldehydes from a marine sponge Siphonodictyon coralliphagum. J Nat Prod 1994, 57(11):1543-1548.

26. Marion F, Williams DE, Patrick BO, Hollander I, Mallon R, Kim SC, Roll DM, Feldberg L, Van Soest R, Andersen RJ: Liphagal, a Selective inhibitor of PI3 kinase alpha isolated from the sponge Aka coralliphaga: structure elucidation and biomimetic synthesis. Org Lett 2006, 8(2):321-324.

27. Shubina LK, Kalinovsky Al, Makarieva TN, Fedorov SN, Dyshlovoy SA, Dmitrenok PS, Kapustina II, Mollo E, Utkina NK, Krasokhin VB, Denisenko VA, Stonik VA: New meroterpenoids from the marine sponge $A k a$ coralliphaga. Nat Prod Commun 2012, 7(4):487-490.

28. Sullivan B, Djura P, Mcintyre DE, Faulkner DJ: Antimicrobial constituents of the sponge Siphonodictyon coralliphagum. Tetrahedron 1981, 37(5):979-982.

29. Grube A, Assmann M, Lichte E, Sasse F, Pawlik JR, Köck M: Bioactive metabolites from the Caribbean sponge Aka coralliphagum. J Nat Prod 2007, 70:504-509.

30. Rosa S, Crispino A, Giulio A, lodice C, Pronzato R, Zabodnik N: Cacospongionolide $B$, a new sesterterpene from the Sponge Fasciospongia cavernosa. J Nat Prod 1995, 58(11):1776-1780.

31. Trimurtulu G, Faulkner JD: Six new diterpene isonitriles from the sponge Acanthella cavernosa. J Nat Prod 1994, 57(4):501-506.

32. Okino $T$, Yoshimura $\mathrm{E}$, Hirota $\mathrm{H}$, Fusetani $\mathrm{N}$ : Antifouling kalihinenes from the marine sponge Acanthella cavernosa. Tetrahedron Lett 1995, 36 (47):8637-8640.

33. Jumaryatno P, Trevor KR, Blanchfield JT, Garsona MJ: Isocyanates in marine sponges: axisocyanate-3, a new sesquiterpene from Acanthella cavernosa. ARKIVOC 2007(vii):157-166. 
34. Sagar S, Kaur M, Radovanovic A, Bajic VB: Dragon exploration system on marine sponge compounds interactions. J Cheminform 2013, 5:11. doi:10.1186/1758-2946-5-11.

35. Geetha I, Manonmani AM, Paily K: Identification and characterization of a mosquito pupicidal metabolite of a Bacillus subtilis subsp. subtilis strain. Appl Microbiol Biotechnol 2010, 86(6):1737-1744.

36. Zimmerman S, Schwartz CD, Monaghan RL, Pleak BA, Weissberger B, Gilfillan EC, Mochales S, Hernandez S, Currie SA, Tejera E, Stapley EO: Difficidin and oxydifficidin: Novel broad spectrum antibacterial antibiotics produced by Bacillus subtilis. J Antibiotics 1987, 40(12):1677-1681.

37. Loeffler W, Tschen JSM, Vanittanakom N, Kugler M, Knorpp E, Hsieh TF, Wu TG: Antifungal effects of bacilysin and fengymycin from Bacillus subtilis F-29-3: A comparison with activities of other Bacillus antibiotics. J Phytopathol 1986, 115(3):204-213.

38. van Dijl JM, Hecker M: Bacillus subtilis: from soil bacterium to super-secreting cell factory. Microb Cell Fact 2013, 12:3. doi:10.1186/1475-2859-12-3.

39. Su J, Jin L, Jiang Q, Sun W, Zhang F, Li Z: Phylogenetically diverse ureC genes and their expression suggest the urea utilization by bacterial symbionts in marine sponge Xestospongia testudinaria. PLOS ONE 2013, 8(5):e64848. doi:10.1371/journal.pone.0064848.

40. Pandey S, Sree A, Dash SS, Sethi DP, Chowdhury L: Diversity of marine bacteria producing beta-glucosidase inhibitors. Microb Cell Fact 2013, 12:35. doi: 10.1186/1475-2859-12-35.

41. Featherstone RM, Andres V Jr, Ellman GL, Courtney KD: A new and rapid colorimetric determination of acetylcholinesterase activity. Biochem Pharmacol 1961, 7:88-95.

42. Rhee IK, van de Meent M, Ingkaninan K, Verpoorte R: Screening for acetylcholinesterase inhibitors from Amaryllidaceae using silica gel thin-layer chromatography in combination with bioactivity staining. J Chromatogr A 2001, 915(1-2):217-223.

43. Reva ON, Sorokulova IB, Smirnov W: Simplified technique for identification of the aerobic spore-forming bacteria by phenotype. IJ SEM 2001, 51:1361-1371.

44. Claus D, Berkeley RCW: Genus bacillus Cohn 1872. In Bergey's Manual of Systematic Bacteriology, Volume 2. Edited by Holt JG, Sneath PHA, Mair NS Sharpe ME. Baltimore, MD: Williams and Wilkins; 1986:1105-1139.

45. Thompson JD, Gibson TJ, Plewniak F, Jeanmougin F, Higgins DG: The CLUSTAL_X Windows interface: flexible strategies for multiple sequence alignment aided by quality analysis tools. Nucleic Acids Res 1997, 25:4876-4882.

46. Tamura K, Peterson D, Peterson N, Stecher G, Nei M, Kumar S: MEGA5: molecular evolutionary genetics analysis using maximum likelihood, evolutionary distance, and maximum parsimony methods. Mol Biol Evol 2011, 28:2731-2739.

doi:10.1186/1475-2859-13-24

Cite this article as: Pandey et al:: A marine sponge associated strain of Bacillus subtilis and other marine bacteria can produce anticholinesterase compounds. Microbial Cell Factories 2014 13:24.

\section{Submit your next manuscript to BioMed Central and take full advantage of:}

- Convenient online submission

- Thorough peer review

- No space constraints or color figure charges

- Immediate publication on acceptance

- Inclusion in PubMed, CAS, Scopus and Google Scholar

- Research which is freely available for redistribution

Submit your manuscript at www.biomedcentral.com/submit
Ciomed Central 